\title{
Is Antibiotic Resistance Microorganism Becoming a Significant Problem in Acute Cholangitis in Korea?
}

\author{
Sang-Heum Park \\ Department of Gastroenterology, Soonchunhyang University Cheonan Hospital, Soonchunhyang University College of Medicine, Cheonan, Korea
}

See "Extended Spectrum- $\beta$-Lactamase or Carbapenemase Producing Bacteria Isolated from Patients with Acute Cholangitis" by Ja Chung Goo, Mun Hyuk Seong, Young Kwang Shim, et al., on page 155-160

Prompt diagnosis and proper management is essential in managing severe acute cholangitis because of its high mortality, which is reported to be up to $10 \% .^{1,2}$ The management of severe acute cholangitis is comprised of two key steps: first, rapid drainage of the obstructed bile duct; and second, administration of systemic antibiotics.

To control systemic infection caused by acute cholangitis, systemic antibiotics via intravenous route should be initiated promptly, in addition to adequate biliary drainage. The main principles for choosing antibiotics for patients with acute cholangitis are 1) to start with broad-spectrum coverage antibiotics, and 2) to change the antibiotics according to the culture and sensitivity test results. ${ }^{3}$ Consequently, information on the causative microorganism is important for adequate selection of antibiotics.

In this issue of Clinical Endoscopy, Goo et al. ${ }^{4}$ revealed that 69 (15.9\%) out of 433 cases of acute cholangitis were infected with any one of the following antibiotic-resistant bacteria, based on blood and/or bile culture; extended spectrum- $\beta$ lactamase producers, carbapenemase-producing bacteria, multidrug resistant Acinetobacter, vancomycin resistance Enterococcus, and methicillin resistance Staphylococcus aureus.

Another significant result to note from Goo's report is the fatality of acute cholangitis. ${ }^{4}$ Despite the vast improvement of biliary drainage techniques and potency of antibiotics in the

Received: May 22, 2012 Revised: May 29, 2012

Accepted: May 30, 2012

Correspondence: Sang-Heum Park

Department of Gastroenterology, Soonchunhyang University Cheonan Hospital, Soonchunhyang University College of Medicine, 31 Suncheonhyang 6-gil, Dongnam-gu, Cheonan 330-930, Korea

Tel: +82-41-570-3892, Fax: +82-41-574-5762

E-mail: pparksh@schmc.ac.kr

(c) This is an Open Access article distributed under the terms of the Creative Commons Attribution Non-Commercial License (http://creativecommons.org/ licenses/by-nc/3.0) which permits unrestricted non-commercial use, distribution, and reproduction in any medium, provided the original work is properly cited. last 10 years, the mortality of acute cholangitis remains as high as $9.5 \%(33 / 346)$. This percentage is no different from previous reports. ${ }^{1,2}$ Goo et al. ${ }^{4}$ argues that this still high mortality rate is due to antibiotic resistance, independent of other prognostic factors such as malignant biliary obstruction and severe cholangitis. This reminds us that antibiotic resistance is related to the increased morbidity and mortality, on top of escalating infection management costs. ${ }^{5}$

However, there are some limitations to this report. Whether adequate biliary drainage was possible or not in patients with advanced malignant biliary obstruction (hilar separation, difficult biliary drainage) and/or other underlying medical diseases was not documented. Furthermore, the authors have failed to document if the antibiotics resistance occurred in antibiotics-naive patients or in those already exposed to previous antibiotics treatment.

Nonetheless, this report successfully raises concerns about increased prevalence of acute cholangitis associated with antibiotics resistant microorganisms, which have been frequently reported in other diseases but only a handful in acute cholangitis in Korea. ${ }^{6,7}$ The next step to take would be performing an epidemiologic survey of antibiotic resistance in patients with acute cholangitis across the country and educating clinicians about the seriousness of antibiotics resistance. The establishment of treatment guidelines in consideration of regional characteristics of Korea should also be considered.

\section{Conflicts of Interest}

The author has no financial conflicts of interest.

\section{REFERENCES}

1. Lai EC, Mok FP, Tan ES, et al. Endoscopic biliary drainage for severe acute cholangitis. N Engl J Med 1992;326:1582-1586.

2. Leung JW, Chung SC, Sung JJ, Banez VP, Li AK. Urgent endoscopic drainage for acute suppurative cholangitis. Lancet 1989;1:1307-1309. 
3. Lee JG. Diagnosis and management of acute cholangitis. Nat Rev Gastroenterol Hepatol 2009;6:533-541.

4. Goo JC, Seong MH, Shim YK, et al. Extended spectrum- $\beta$-lactamase or carbapenemase producing bacteria isolated from patients with acute cholangitis. Clin Endosc 2012;45:155-160.

5. Hawkey PM, Jones AM. The changing epidemiology of resistance. J Antimicrob Chemother 2009;64 Suppl 1:i3-i10.
6. Sung IK, Lee KT, Lee JK, et al. Bacteriological study of bile in patients with cholangitis due to biliary tract obstruction. Korean J Med 1998; 55:28-33.

7. Heo JH, Lee JH, Lee MY, et al. Bacterial identification in bile and blood of patients with acute cholangitis from benign and malignant bile duct obstruction. Korean J Gastroenterol 2002;40:53-59. 